\title{
STOP 11: Recessional moraine ridge at Veresovka, Rāzna glacial depression
}

\author{
Vitālijs Zelčs ${ }^{\mathrm{a}}$, Juris Soms ${ }^{\mathrm{b}}$, Aivars Markots ${ }^{\mathrm{a}}$ and Ivars Strautnieks ${ }^{\mathrm{a}}$ \\ ${ }^{\mathrm{a}}$ University of Latvia, Latvia \\ ${ }^{\mathrm{b}}$ Daugavpils University, Latvia
}

A recessional moraine ridge at Veresovka village stretches for a distance of $0.5 \mathrm{~km}$ along the eastern shore of Lake Rāzna, south of the River Rēzekne outflow (Fig. 11.1). It is located proximally from the Kaldabruna ice-marginal zone, inside a relatively broad glacial depression occupied by the Ràzna glacier tongue during the earliest deglaciation phases of the Latgale Upland, when the Lubāns ice lobe terminated here as a series of glacier tongues (Meirons, 1975; Zelčs and Markots 2004; Zelčs et al. 2011). Interlobate hummocky moraines that terminate on both sides of the glacial depression and trend transverse to the ice-marginal zone are regarded as convergence zones between the Rāzna and Malta tongues in the southwest, and the Rāzna and Cirma tongues in the north-east (Fig. 11.1).

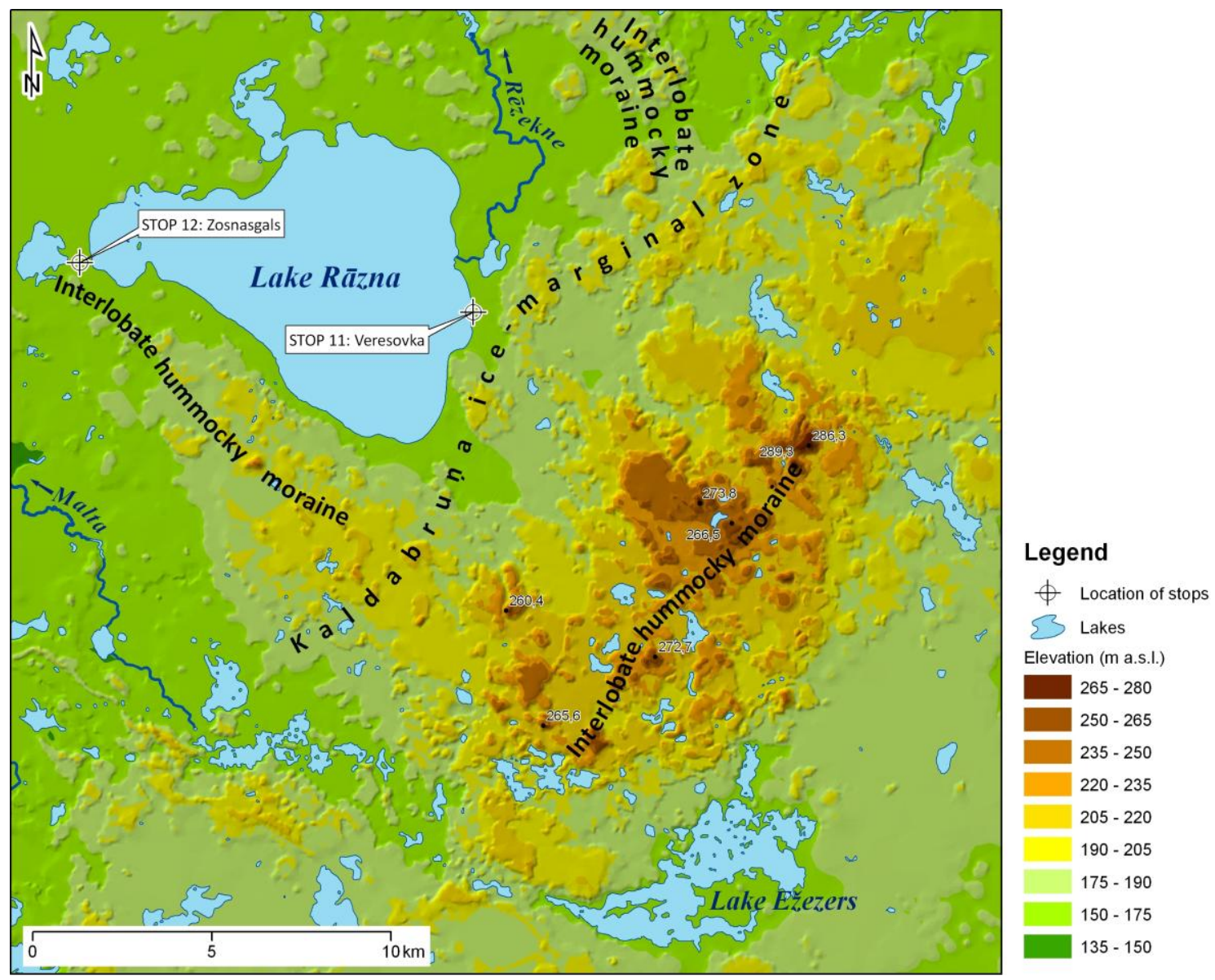

Fig. 11.1. Topography of the surroundings of Lake Rāzna, showing the study area.

The Rāzna glacial depression and the Kaldabruña ice-marginal zone are situated upglacier from the highest part of the Latgale Upland, occupied by an impressive interlobate hummocky moraine ridge rising between the Lubāns and Polatsk ice lobes (Fig.11.1). The moraines formed transversely and are not oriented to the ice flow direction. Streamlined features as well as stagnant ice topography alternate with smoother surfaces of narrow strips of glacial plains, indicating diversity and spatio-temporal superimposition of glacial 
lithomorphogenetic processes in the depression as a result of glaciodynamic changes during the course of thinning of the Rāzna tongue. Even though the lower part of the glacial depression is occupied by lakes and mires, some glacial features may also be found in the bottom topography of Lake Rāzna (Fig. 11.2).

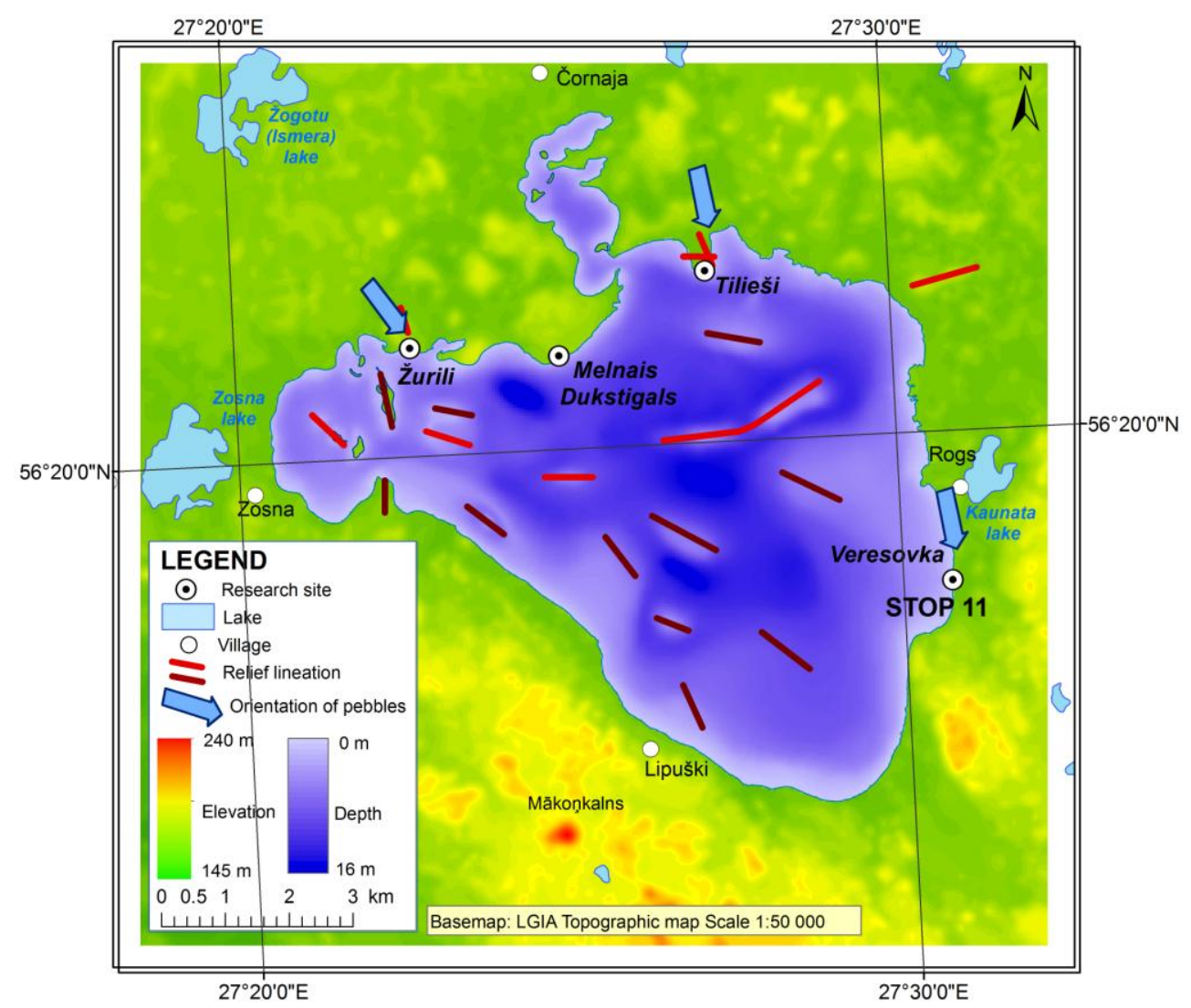

Fig. 11.2. Suspected glacial features of the Lake Rāzna bottom topography. Dark brown lines denote streamlined glacial landforms, while red lines indicate the position of the recessional moraine, stretching across the lake. Arrows indicate the dominant macrofabric linearity in subglacial till.

The Rāzna glacial depression corresponds to an elongated bedrock/pre-Weichselian depression. The bedrock surface dips slightly to NW. In the lower part of the depression its hypsometric position is less than $106 \mathrm{~m}$ a.s.l., increasing to $114-119 \mathrm{~m}$ a.s.l. on both sides. The bedrock is Upper Devonian clay, dolomite and gypsum. The Kaldabruna ice marginal zone coincides with a gentle slope consisting of Upper Devonian dolomite. The thickness of the Pleistocene deposits varies from 50-60 $\mathrm{m}$ to 70-85 $\mathrm{m}$. The maximum thickness occurs on the highest part of the interlobate hummocky moraine and ice-marginal ridge. Mākoņkalns Hill (Wolkenberg), which is located in the distal portion of the interlobate zone and is the highest point in the adjoining area, reaches $247.4 \mathrm{~m}$ a.s.l., while the elevation of the Kaldabruņa ice-marginal ridge varies from $180 \mathrm{~m}$ to $215 \mathrm{~m}$ a.s.l.

The maximum elevation of the recessional moraine ridge at Veresovka is $169.8 \mathrm{~m}$. It rises 5-7 m above the lake level and almost $25 \mathrm{~m}$ above the deepest part of Lake Rāzna. Even though the proximal part of the moraine ridge has almost been washed out by wave activity in the lake, several outcrops along the lakeshore give an insight into the internal structure of this small, smooth-crested ice-marginal ridge, which marks a halt in the retreat of the Rāzna glacier tongue.

In general, the ridge is composed of sediments that have been deposited in subglacial, supraglacial and ice-marginal environments. Observations of internal structure provide 
evidence of glacial thrusting (Figs. 11.3 and 11.4) and/or mass movement (Figs. 11.5 and 11.6). Small, up to 3-m-thick thrust-faulted structures form a regressive series (Figs. 11.3 and 11.4) and are responsible for redistribution of the inicial thickness of the diamicton and ice contact stratified drift in the course of formation of the recessional moraine ridge.

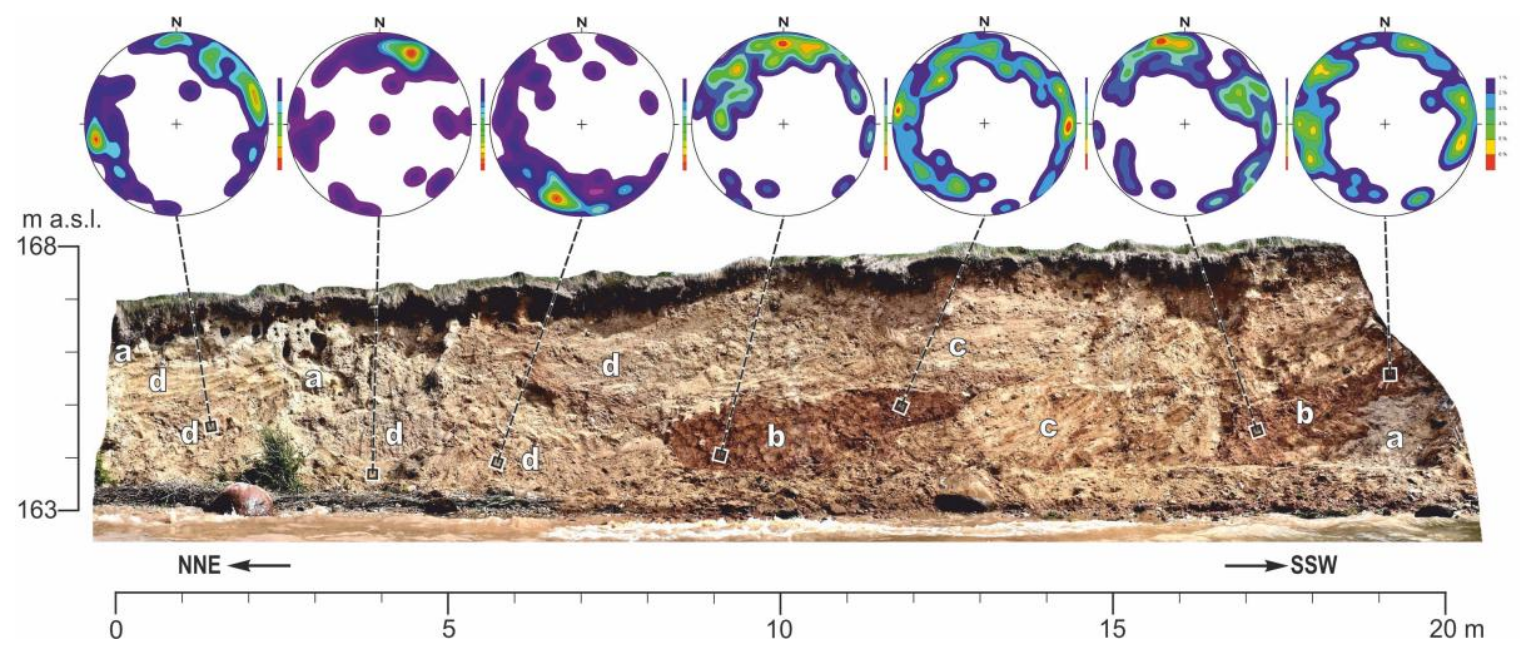

Fig. 11.3. Internal structure of the northernmost part of the recessional moraine in a section subparallel to the ridge crest. Legend: a - deformed sandy gravel with occasional cobbles; $b$ - moderate brown, massive, densely compacted, basal clayey sand diamicton (subglacial till); c -deformed stratified diamictic gravelly sand with chunks of laminated fines and diamicton lenses (supraglacial diamicton); d - matrix supported supraglacial diamicton.

Three-dimensional diagrams of till macrofabric are plotted on the lower hemisphere and in equal area projection. Based on 50 elongated clast measurements. Contoured at 0-1-2-4...14-16 percent areas.

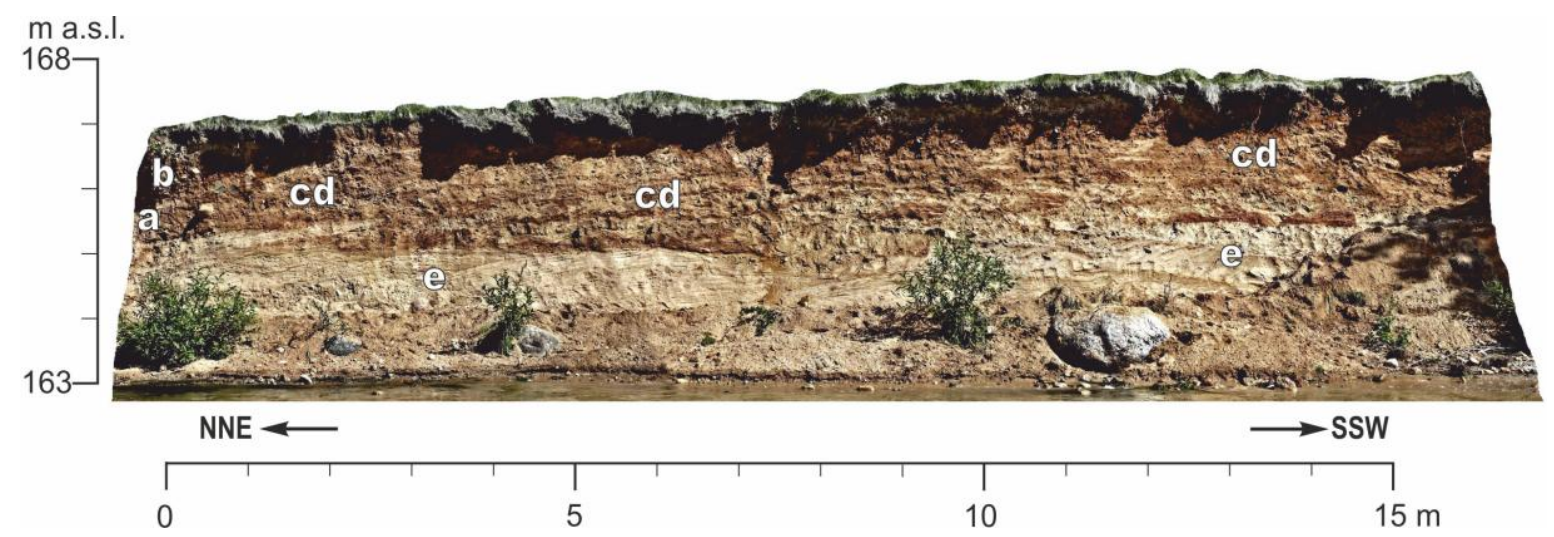

Fig. 11.4. Internal structure of the recessional moraine in a section located $7 \mathrm{~m} \mathrm{~S}$ of the section shown in Fig. 11.3. The section is subparallel to the ridge crest. Legend: $a$ - deformed sandy gravel with occasional cobbles; $b$ - moderate brown, massive, densely compacted, basal clayey sand diamicton (subglacial till); cd - deformed matrix supported diamictic sand with gravel and diamicton lenses (supraglacial diamicton); e - sheared trough cross-stratified and rippled gravelly sand, interlayered with silt and silty clay.

The imbricately stacked thrust scales largely consist of subglacial till derived from the glacier bed and supraglacial diamicton (Figs. 11.3 and 11.5), as well as supraglacial diamicton with sheared stratified drift (Fig. 11.4), or of altered stratified sediments in the southernmost part. As a result of thrusting, supraglacial till has been incorporated into the upper parts of the thrust scales (Fig. 11.3). The supraglacial till contains lenses and intercalations of stratified material with imprints of plastic and disruptive minor deformation. The weak multimodal macrofabric maxima, predominantly parallel to the recessional moraine crest and almost subperpendicular to ice flow direction, most likely indicate that subglacial till has been plastered 
onto a glacier bed in some earlier phase when the Rāzna tongue terminated at the Kaldabruna ice marginal zone. The wide dispersion of macrofabric lineation can be explained by its reorientation during formation of thrust-fault scales. In the section shown in Fig. 11.3 subglacial till is relative homogenous, but in the section shown in Fig. 11.5 it contains features common for subglacial deformation till. This till contact with the underlying supraglacial till is marked by a shear plane. In comparison to tills occurring in the northern part of recessional ridge, macrofabric linearity is quite strong and parallel to ice flow, while the macrofabric as well as the bedding planes dip downglacier. In the supraglacial till clast orientation maxima change from place to place and are rather chaotic. It is likely that the sandy gravel with occasional cobbles at the margin formed as ice-marginal fans due to re-deposition of the supraglacial diamicton, later reshaped by proglacial thrusting or flowage of diamicton above them.

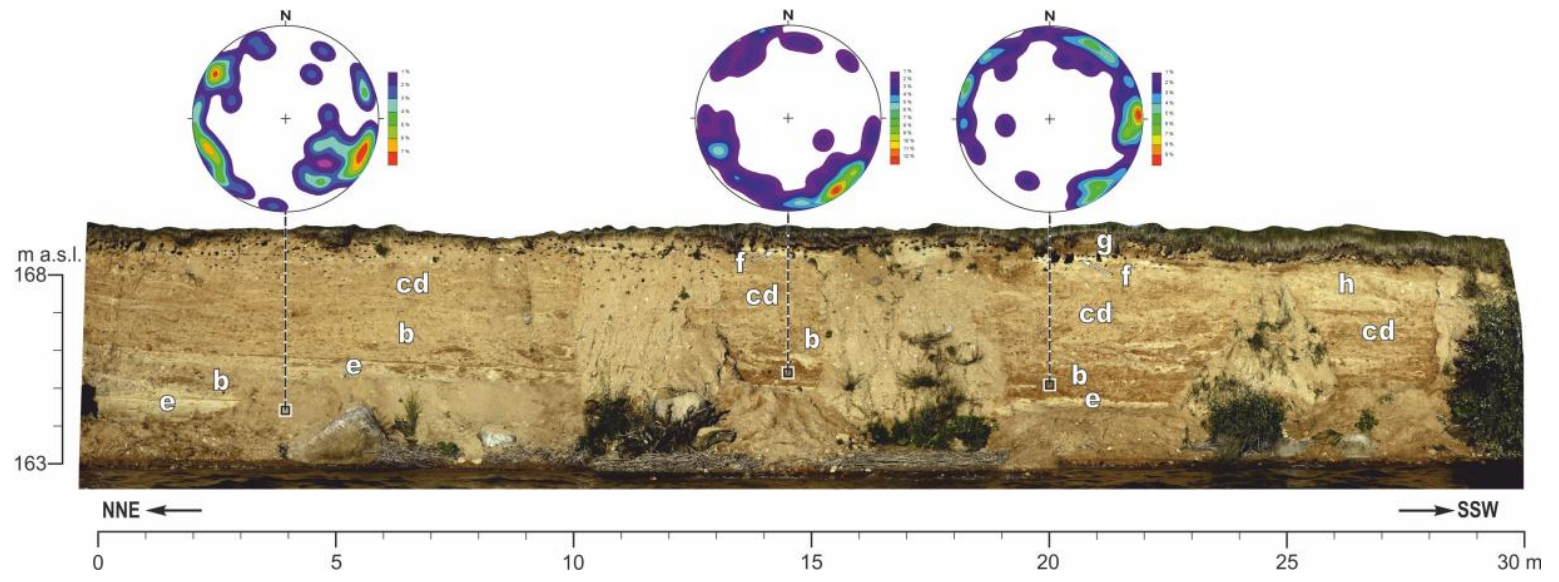

Fig. 11.5. Internal structure of the highest part of the recessional moraine ridge in a longitudinal section located $13 \mathrm{~m} \mathrm{~S}$ of the section shown in Fig. 11.4. Legend: $\mathrm{b}$ - moderate brown, basal clayey sand diamicton with deformed incorporated gravelly sand and finer material (subglacial till); cd - deformed matrix supported diamictic sand with gravel and diamicton lenses (supraglacial diamicton); e - sheared trough cross-stratified and rippled gravelly sand, interlayered with silt and silty clay; $\mathrm{f}$ - carbonate cemented sands; $\mathrm{g}$ - thinly laminated silt and clay with dropstones.

Three-dimensional diagrams of till macrofabric are plotted on the lower hemisphere and in equal area projection. Based on 50 elongated clast measurements. Contoured at 0-1-2...11-12 percent areas.

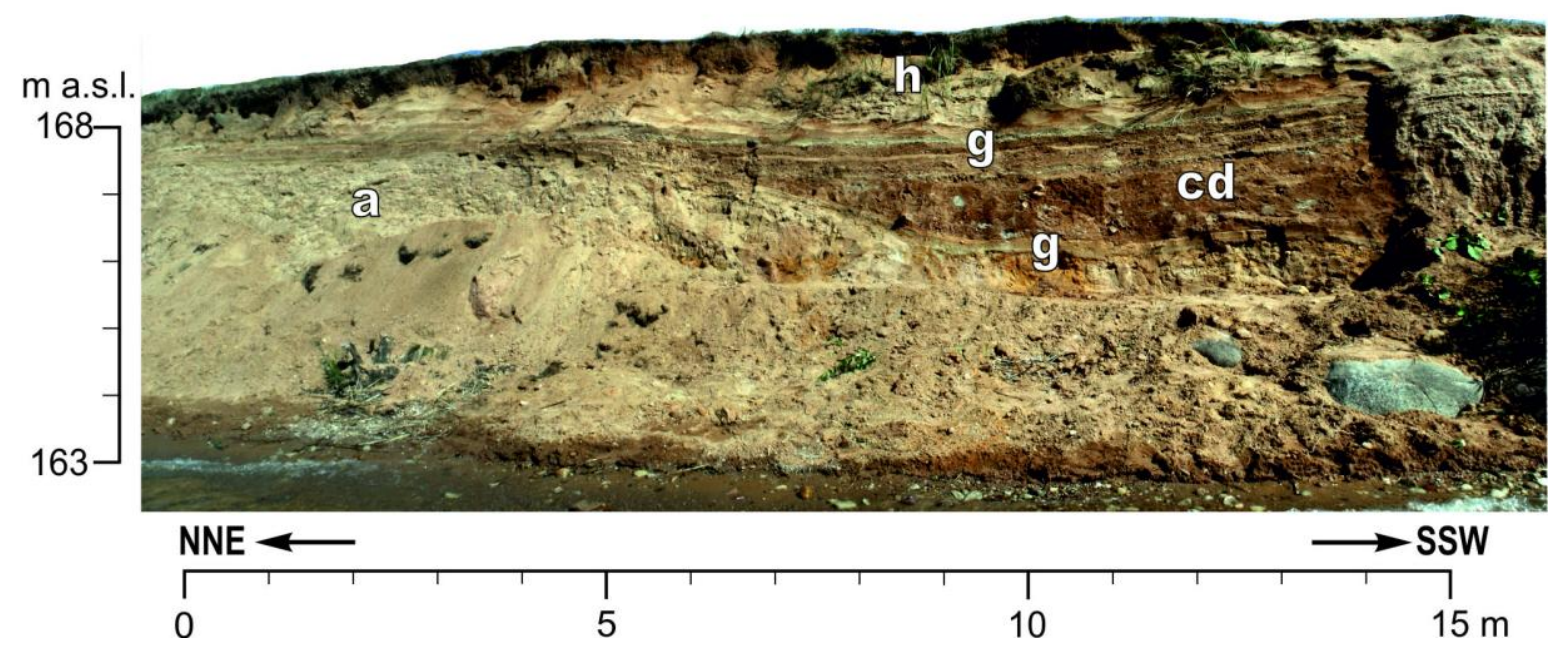

Fig. 11.6. Internal structure of the southern part of the recessional moraine ridge in a longitudinal section located $13 \mathrm{~m} \mathrm{~S}$ of the section shown in Fig. 11.5. Legend: a - deformed sandy gravel with occasional cobbles interlayered with sand; cd - deformed matrix supported diamictic sand with gravel and diamicton lenses (supraglacial diamicton); $\mathrm{g}$ - thinly laminated silt and clay with dropstones; $\mathrm{h}$ - coversand. 
In general, the internal structure and lack of subglacial meltwater drainage features attest that during formation of the recessional moraine ridge at Veresovka the glacier marginal part was frozen to the bed and longitudinal compressive ice flow conditions prevailed, which resulted in the formation of a small ice-marginal ridge. Evidently, the Rāzna tongue was covered by supraglacial drift. According to the exposed sequence (Figs. 11.3, 11.4 and 11.5) its maximum thickness could reach up to $2 \mathrm{~m}$. It might be assumed that supraglacial drift was effectively protecting the ice from melting and resulted in down-wasting of the glacier in situ, rather than an evident retreat of the glacier tongue terminus. Probably this and cold glacierbed condition also promoted also the formation of a solitary ridge instead of small composite ridges (according to the terminology of Aber et al. 1989).

\section{References}

Aber, J.S., Croot, D.G., Fenton, M.M. 1989. Glaciotectonic landforms and structures. Kluwer Academic Publishers, Dordrecht/Boston/London/, $201 \mathrm{pp}$.

Meirons, Z. 1975. The relief of the Latgale Elevation and the bordering areas of the East-Latvian Lowland. In Danilāns, I. (ed.), Problems of Quaternary Geology, 8. Rīga, Zinātne, pp. 48-81 (in Russian).

Zelčs, V., Markots, A. 2004. Deglaciation history of Latvia. In: Ehlers, J., Gibbard, P. L. (eds.), Quaternary Glaciations - Extent and Chronology. Part I: Europe. Developments in Quaternary Science, 2. Elsevier, Amsterdam, pp. 225-243.

Zelčs, V., Markots, A., Nartišs, M., Saks, T. 2011. Chapter 18: Pleistocene Glaciations in Latvia. In: Ehlers, J., Gibbard, P.L., Hughes, P.D. (eds.), Quaternary glaciations - extent and chronology. A closer look. Developments in Quaternary Science, 15. Elsevier, pp. 221-229. 

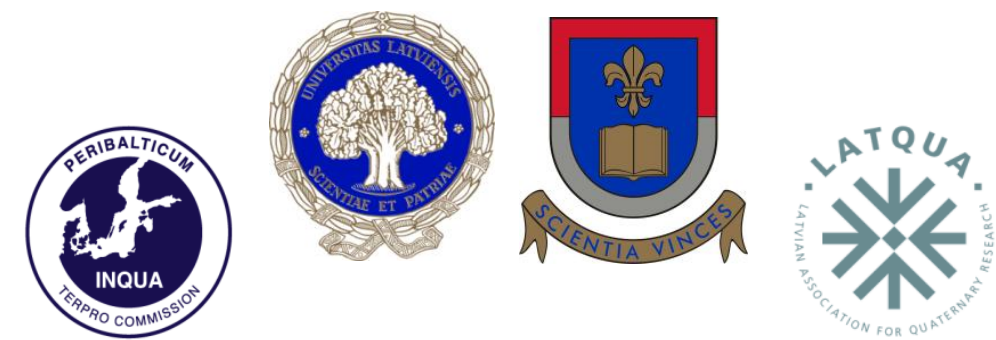

INQUA TERPRO COMMISSION PERIBALTIC WORKING GROUP

UNIVERSITY OF LATVIA

UNIVERSITY OF DAUGAVPILS

LATVIAN ASSOCIATION FOR QUATERNARY RESEARCH

\section{LATE QUATERNARY \\ TERRESTRIAL PROCESSES, SEDIMENTS AND HISTORY: FROM GLACIAL TO POSTGLACIAL ENVIRONMENTS}

EASTERN AND CENTRAL LATVIA

AUGUST 17-22, 2014 


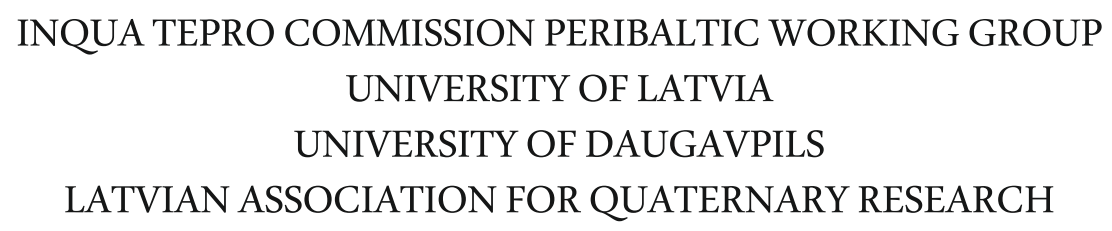

\title{
LATE QUATERNARY \\ TERRESTRIAL PROCESSES, SEDIMENTS AND HISTORY: FROM GLACIAL TO POSTGLACIAL ENVIRONMENTS
}

\author{
EASTERN AND CENTRAL LATVIA
}

AUGUST 16-22, 2014 
Organized by:

University of Latvia

Daugavpils University

Latvian Association for Quaternary Research

INQUA Peribaltic Working Group (INQUA TERPRO Commission)

Organizing committee:

Māris Nartišs (Chair, University of Latvia)

Māris Krievāns (Secretary, University of Latvia)

Aivars Markots (University of Latvia)

Juris Soms (Daugavpils University)

Evija Tērauda (University of Latvia)

Vitālijs Zelčs (University of Latvia)

Contributors:

Ivars Celiņš, Edgars Greiškalns, Ieva Grudzinska, Edyta Kalińska-Nartiša, Laimdota Kalniņa, Jānis Karušs, Māris Krievāns, Kristaps Lamsters, Aivars Markots, Māris Nartišs, Agnis Rečs, Normunds Stivriņš, Juris Soms, Ivars Strautnieks, Santa Strode, Sandra Zeimule, Vitālijs Zelčs

Editors: Vitālijs Zelčs and Māris Nartišs

The English texts of the field guide were revised by Valdis Bērziņš

Recommended reference for this publication:

Zelčs, V. and Nartišs, M. (eds.) 2014. Late Quaternary terrestrial processes, sediments and history: from glacial to postglacial environments. Excursion guide and abstracts of the INQUA Peribaltic Working Group Meeting and field excursion in Eastern and Central Latvia, August 17-22, 2014. University of Latvia, Rīga, 2014, 150 pages.

Sponsored by:

University of Latvia

Layout: Vitālijs Zelčs, Māris Nartišs and Māris Krievāns

ISBN 078-9934-517-60-0

(C) University of Latvia, 2014

This volume is available from:

Faculty of Geography and Earth Sciences

University of Latvia

Rainis Blvd. 19

Rìga, LV1586

Latvia 